\title{
User Education and its Present Status in University Libraries in Sri Lanka: An Overview
}

Lalith Wickramanayake ${ }^{1}$

\begin{abstract}
The rapid development of information and communication technology (ICT), particularly internet, and the increasing development of user education forms and methods, such as new information literacy initiatives have resulted in significant changes in academic libraries. With these unprecedented changes, academic librarians in Sri Lanka have to deal with instructional processes more effectively and efficiently. The primary concern of this paper is to understand the concept 'user education' in the local context and its present practices in university libraries. Even more, this study intends to understand problems encountered, challenges being faced and potential new opportunities available on user education in university libraries in Sri Lanka. The total outcome of this paper is beneficial for researchers, policy makers, university authorities and academic librarians in Sri Lanka to understand the real situation which exists behind instructional activities of university libraries and to design, develop, implement policies and make strategies on pertinent subject.
\end{abstract}

Keywords: User education, Library orientation, Bibliographic instruction, Library instruction, Information literacy, Online library instruction

\section{Introduction}

\section{Gradual Movement of User Education}

User education is a much more complex practice in academic library settings than in other types of libraries in the present information society. The literature on user education in academic libraries is vast (Downard, 1992) and the concept has been understood by different people in different ways (Chopra, 2001). Yet, traditionally there were various forms of user education such as

\footnotetext{
${ }^{1}$ Senior Assistant Librarian, Faculty of Agricultural Sciences, Sabaragamuwa University of Sri Lanka.Email:wwk@lib.sab.ac.lk
} 
'library orientation', 'library instruction', 'bibliographic instruction', 'information skills courses', 'on-line instruction' and 'course-related instruction', and various instructional methods and media, such as 'library tour' and 'audio-visual materials' (Downard, 1992). The literature published in the field of library and information science provides substantiation that the above user education methods have a considerable history and information literacy that evolved from those precursors (Fjällbrant \& Malley, 1984; Rader, 1991; Snavely \& Cooper, 1997; Julien, 1998; Fjällbrant, 2000; Bruce, 2000; Homann, 2001; Seaman, 2001; Sinikara \& Järveläinen, 2003; Weiss, 2003; Virkus \& Metsar, 2004; Campbell, 2004). According to Seaman, (2001), though instruction activities in library field have developed in the past 150 years, information literacy has only less than 25 years of history.

Historical and chronological studies on user education have not been done by the majority of countries in the world. This means that only some industrialized countries have done such studies (Seaman, 2001; Manchester Metropolitan University, 2007; Virkus, 2003); Willingham, Carder \& Millson - Martula, 2006). This is because these countries have evolved for the methodical development of the field of Library and Information Science and also for the development of library profession. The other countries categorized as under developed or developing have not taken considerable measures to record or study the historical development of user education.

Despite this fact, the present practices of information literacy instruction are more complex than the early forms of instruction methods. Although, traditional instruction methods such as library orientation, library instruction, bibliographic instruction etc. are usual practices of librarians' day to day activities, the real information literacy is a much broader concept and cannot achieve instantly from a short seminar or a workshop (McCartin, 2001) because it is a multifaceted subject by nature. It discusses different facets of learning objectives of higher education. Hence the role of information literacy in higher education focuses on the development of effective research activities, critical thinking, library skills, communication skills, technological skills and ultimately lifelong learning of students (Doyle, 1994). 
As Breivik (1999) explained library instruction and bibliographic instruction involve teaching facts directly to the people, while information literacy involves the development of self-learning, independent and self-directed research and life-long learning of students aiming at their positive contribution to the society. It is not only a subject that is taught by librarians or faculty, but a subject that must be learned by students through experiences shaped by librarians and faculty.

Grafstein (2002) clarifies how the increasing development of information and communication technology has affected the transformation of traditional user education into information literacy; "The concept of IL developed and grew largely in response to the expanding variety of information formats that were available to students, many of which were becoming increasingly accessible beyond the walls of the library" (p. 197). Butcher (1999); Virkus and Metsar (2004); Bewick and Corrall (2010) were also of the opinion that the unprecedented transformation of academic libraries and their functions have appeared due to increasing development of information and communication technology. As Wilson and Halpin (2006) and Yi (2005) explain, most academic libraries today are hybrid libraries due to these developments.

In addition, the rapid development of information and communication technology changed the role of libraries in higher education. It directed libraries to form new accreditation standards, emphasized the requirement to review and reform curricular, stimulated to introduce integrated learning and learner-centred education (Warnken, 2004). In fact, the development of information and communication technology has affected the every segment of information literacy and has created a much complex environment in user education (Cowgill et al., 2001). Besides, the tremendous growth of information and communication technology has particularly changed and expanded the academic librarians' instructional activities and performances as well. Hence the academic librarians today ought to be clever in pedagogy, curricular, digital environment and information and communication technology. Even more, they have to have a good collaboration with the faculty to create an effective and efficient information literacy learning environment in universities (Bridgland \& Whitehead, 2004) because "the 
systematic approach once used in traditional bibliographic instruction programs can no longer be effective" (Warnken, 2004, p. 154).

The new avenues which appeared in user education due to the above developments are mostly influenced on academic libraries - especially for university libraries. Thus, the academic librarian's traditional role as instructor also has significantly changed because of the emergence, development and proliferation of information literacy instruction initiatives and information and communication technology (Warnken, 2004). Bewick and Corrall (2010) emphasized that the newly emerging trends in higher education, new learning and teaching approaches in universities, new student centered models, and social, political, financial, and management issues have formed new roles and responsibilities for academic librarians. Even more, with these tremendous changes and rapid developments, the continuing professional development activities of academic librarians have expanded and changed dramatically, which in turn has directly affected their instructional performance.

This circumstance has greatly influenced the teaching performance of academic librarians in developing countries than in industrialized countries. As Ashoor (2005) highlighted, the three major concerns that the librarians in developing countries are confronting on developing user education are traditional educational system, the low literacy rate, and the low level of publishing. According to Lwehabura and Stilwell (2008), many developing countries have not yet seriously been considered about user education specially about information literacy. Thus, the instruction activities in these countries are considerably weak due to ineffectiveness of knowledge and skills development activities. In addition, unavailability of dedicated library instruction / information literacy policies for most of the institutions, lack of awareness among students about the instruction sessions, poor attendance of students (for non-credit /optional courses), time constraints for user education among academic timetables, shortage of well-trained human resources, unavailability of adequate physical resources etc. have negative effects on development of instruction activities in academic libraries. Moreover, as Lwehabura and Stilwell (2008) clarified, lack of proactivity by librarians in instruction, poor faculty library collaboration and scarcity of support from all 
the university stakeholders are barriers to the development of information literacy.

As in most developing countries, the prevailing situation of user education in university libraries in Sri Lanka is indiscriminate. The majority of them, as disclosed by some studies (e.g. Jayatissa, 2008; Jayatissa, 2009; Mashroofa, 2009; Seneviratne, 2009; Ranaweera, 2010; Wickramanayake, 2014), are gradually moving from traditional user education methods to information literacy while some of them are still practising traditional methods even though they have understood the urgent need to implement information literacy initiatives in their institutions. Yet, unavailability of considerable previous publications including research reports creates obstacles to this task and discomfits the reviewing process.

However, there is an urgent need to review the current library instruction activities which are being carried out by academic librarians in Sri Lankan universities. Such a review, in turn, will help to distinguish the changing role and duties of academic librarians as instructors. The primary concern of this review is to understand the degree and type of instruction provided and the problems, challenges and potential opportunities which may have impact on user education and measure how librarians should set about providing instruction. The article provides an overview of the user education or library education activities in university libraries by reviewing some previous studies. This means that the other types of academic libraries in the country are excluded from the study. Though this selection creates some limitations, this review is very useful for academic librarians to understand their current position as instructors and to reconsider their role in library instruction, which would directly help them to enhance their instructional competencies. Although, this review is primarily concerned with university libraries in Sri Lanka, it makes use of literature pertaining to both developed and developing countries due to the absence of considerable literature in the context of Sri Lanka.

\section{User Education through Online Media}

Few decades back - even before the invention of internet, libraries used diverse media such as audio cassettes, video tapes, overhead projectors, multimedia 
projectors, subject guides, pathfinders and more to deliver library orientation, library instruction, bibliographic instruction etc. These media were used in face to face teaching or as self-faced learning methods. However, with the development of information and communication technology and the invention of internet, most of these techniques were replaced by online library instruction.

Online or web based instruction, most of the times, is considered as distance learning method in educational studies (Oblinger, Barone, \& Hawkins, 2001) and is developed to be used anytime, anywhere and sometimes any one. In addition, this method helps librarians to reach large number of audience at the same time. There is no space or time limitation (Smith, 1010). Warnken (2004) was of the opinion that the introduction of web based instruction or online instruction was heavily influenced on instructional role of the librarians. Making her attention on online library instruction, Dewald (1999) stressed how online instruction significantly affected traditional library instruction to distinguish its function from each other.

Furthermore, web based instruction most extensively affected information literacy skills development among the students (Sacchanand \& Jaroenpuntaruk, 2006). As Townley and Myers (1995) explained, it is not an easy task to formulate a well-defined online information literacy program. Further, their article gives us an impression that electronic instruction should address gradually from the simple reference answering process to much detailed courses like information literacy.

Even more, the web based instruction influences teaching and learning process due to its integration into the curriculum. Ragains (2001) is also of the opinion that the course related web sites which were developed in response to the faculty request for library orientation can maximize library instruction. The development of course related website is not an easy task because the relevant information for such websites should be included based on the librarian's subject knowledge, information gathered from course syllabi and direct contact with students and faculty. Making her deeper attention on the development of web based library instruction, Meer (2000) explains how the 
web was increasingly used as diverse instructional application to deliver library guidance and instruction.

Nevertheless, by paying closer attention to the websites of most of libraries in higher educational institutions in the world, one can understand that the web based library instruction is a recent trend. As most studies confirmed, it has more advantages than onsite or face to face library instruction. However, as McMullen (2001) clearly mentioned, the adaptation of this new technology for library instruction keeps library users away from the physical library and its physical and human resources. Yet, like onsite or face to face library instruction, web based or online library instruction is mostly utilized by developed countries. Though most of the universities in developing countries have added some web based instruction elements in to their websites, majority of them are either incomplete, broken link or under construction. The prevailing situation in the context of Sri Lanka also is not different from that of many developing countries. As Wickramanayake (2012) confirmed, online library instruction activities in majority of websites in Sri Lankan universities are either non-available, incomplete, broken link or under construction.

\section{User Education in Academic Libraries in Sri Lanka}

Today, academic librarians are required to act beyond the traditional role of acquiring, organizing, disseminating and preserving information. They are expected to educate users on effective and efficient ways of information retrieval, evaluation and usage in addition to fulfilling their traditional roles (Jayatissa, 2008; Seneviratne, 2009). Moreover, "They require new and refined skills and conceptual understanding which will enable them to perform with an educational competence and professional confidence equal to that of their academic peers" (Peacock, 2001, p.1).

Despite this fact, as Jayatissa (2009) emphasizes, contemporary academic librarians in Sri Lanka have been playing traditional, professional and managerial roles along with the teacher's/ instructor's role concurrently. Sri Lankan university libraries have equally understood their role in user education for several decades back (Jayatissa, 2008; Jayatissa, 2009). In fact, most of the well-established universities in the country began their user education programs early in the seventies (Seneviratne, 2009) and eighties 
(Jayatissa, 2009; Hindagolla, 2012). Although such programs have been in place for several decades, the availability of publications not only on development of library instruction but also on information literacy is very rare (Wijetunge, \& Wilson, 1998; Wijetunge, 1998). Though this statement is somewhat outdated, the situation remains unchanged.

This may be due to the fact that the formal and well defined user education programs in academic libraries are not widely practiced. "Although librarians accept that user education is beneficial, no substantial efforts have been made for initiating and strengthening library user education programs in universities in Sri Lanka" (Rathnayake, 2004, p. 55). Most university libraries conduct their own library instruction programs which do not fit with any national or international standard or model. This means that they practice their own instructional methods to educate their users to be well suited with their own library environment. Some of their instructional practices have direct relationship with information literacy, while some of them are merely conventional library instruction practices. Consequently, most of the information literacy programs in Sri Lankan higher education system cannot be purely extracted from existing library instruction programs.

Nevertheless, during recent years, there has been a significant interest in information literacy in Sri Lanka. This might be due to the introduction of 'Empowering 8'information literacy model in 2004 by targeting the school sector in the country (Wijetunge \& Alahakoon, 2005) and the availability of several information literacy workshops and training programs locally during the past few years. This new awakening has had impact on the higher education sector as well, especially the country's university libraries. This can be illustrated by some papers published and presented in academic journals and in symposiums and number of information literacy programs which have been introduced by some universities through their websites (Wickramanayake, 2012).

\section{Present Situation and Future Expectation of User Education in Academic}

\section{Libraries in Sri Lanka}

Commencement, development and practice of any type of user education program in university libraries in developing countries depend on different 
phenomena. Among these, insufficient money, scarcity of staff and training facilities and physical and human resources, negative attitudes of university administration, teaching faculty, students and librarians, tepid attitudes of librarians etc. negatively affect the above process. The university libraries in Sri Lanka also have to face these problems, since Sri Lanka is also a developing country in the southern region of Asia. However, since the major goal of this article is to review available literature on user education in Sri Lankan university libraries, the author collected some publications (e.g. Jayatissa, 2008; Jayatissa, 2009; Mashroofa, 2009; Seneviratne, 2009; Ranaweera, 2010; Wickramanayake, 2012; Wickramanayake, 2014) conducted on user education in the local context. This reviewing process aids these pieces of works to present the real picture of the country's current library instruction practices which is timely most important for the better understanding of librarians, policy makers and university administrators to design, develop and implement such programs in an effective manner.

\section{Problems Encountered}

The above studies provide substantiation that the Sri Lankan university libraries are considerably traditional organizations. Most of them do not have well defined user education programs developed based on institutional or national instruction policies. As some studies confirm, majority of them practice their own instructional methods to educate their users to be well suited with their own library environment. This situation creates some critical national issues which affect the instructional objectives of the university libraries. As included in the recent policy statement of the Sri Lankan government, Sri Lanka wants to be the education hub in south Asia. In order to help the government to reach its target, the national universities - specially university libraries, have incommensurable responsibility. In this regard, all the university libraries should reform their user education methods by considering all the advantages of moving from traditional education methods to information literacy instruction since the concept of information literacy means different facets of learning objectives of higher education. It ".....represents a more sophisticated conceptualization of the librarian's role and relationship to the client, as well as to that of content design and delivery" (Peacock, 2001, p. 1). However, as the above studies highlighted, instructional 
practices in some libraries have direct relationship with information literacy, while some of them are merely conventional library instruction practices.

Nonetheless, the above mentioned literature demonstrates that university libraries have encountered a variety of problems and issues with relation to present practices of user education. Among these, as Wickramanayake (2014) identified, around $50 \%$ university libraries do not take necessary efforts to fulfill library goals and objectives in relation to library instruction. As early as 1977, Fjällbrant (1977) and later on Downard (1992) explained that the library instruction programs in any library should include well defined goals and objectives which necessarily match with the general aims of the university library. Also these terms must in turn be related to the goals and aims of the higher education. But the problem encountered in this regards is whether the librarians have much concern about this phenomenon in Sri Lanka. The literature discussed above provides evidence that this is a somewhat blurred area in user education in university libraries in Sri Lanka.

In addition, for the success of user education programs, different phenomena such as financial, administrative and attitudinal issues are needed. As Rathnayake (2004) identified, lack of physical resources, poor faculty-library collaboration, inadequate time for preparation, poor planning and students' poor attendance comprise the major constraints for conducting instruction programs. Hindagolla (2012) discloses that although the library provides a number of services and facilities for its users, the majority of students are not aware about most library services owing to the limited coverage of the instructional methods. In addition, the students are not satisfied with the existing user education programs due to different factors such as unsuitable time slots, insufficient awareness on e-resources, insufficient coverage of study areas, too much students for one group, insufficient information of the program and limited duration of the program.

By assessing instructional performance of academic librarians, Wickramanayake (2014) has revealed some critical issues which academic librarians currently face. As he confirms, although most university libraries have qualified academic librarians with good teaching experiences, only a few academic librarians have been appointed as instruction coordinator/ 
instruction librarian/ head of instruction to manage instruction activities. This means that most instruction activities in the majority of university libraries are coordinated by (chief) librarians. Moreover, this study reveals that the academic librarians in universities have covered certain important library instruction methods for students from time to time. Though the academic libraries had used assessment instrument to measure students' satisfaction with library instruction from time to time, they had hardly ever used such measures to evaluate faculty's satisfaction with library instruction. In addition, academic libraries had not taken considerable effort to test students' library skills and application of such skills for day-to-day learning activities. The results further confirmed that the academic librarians were much interested library orientation programs rather than conducting library instruction / bibliographic instruction programs and also they had covered certain important library instruction concepts less frequently. They had paid much more attention to some concepts, which were merely on finding information.

At the end of the analysis of the paper, the author marked very interesting comments which were given by the respondents of the study. Since all these comments are very relevant to the real problems that they face while conducting library instruction, it is worth marking them. As highlighted in the paper, some academic librarians declare that the curricula of their universities had not been designed to provide room for library instruction or information literacy programs and that their teaching faculty and university administration were reluctant to allocate several periods for library activities in their teaching time tables. In addition, the university administrations and faculties had not understood the importance of the implementation of information literacy for institutional teaching. Thus, some academic librarians suggested that the university administrations and faculties should change their attitudes and become thoroughly aware of the importance of information literacy for their universities.

Furthermore, some academic librarians mentioned that they were not invited when the university had workshops, seminars, trainings, etc. related to academic and teaching development. According to some academic librarians, they were not invited to serve on curriculum revision committees. Therefore, they could not keep in touch with curriculum development, revision and 
evaluation process in the universities. Moreover, some academic librarians stated that the university administrations and faculties had neglected them. In addition, some respondents declared that the university culture had not accepted academic librarians teaching as a requirement for teaching and learning process. Besides, some academic librarians affirmed that they were not provided enough funds for training, materials, instruments and resources. The other obstacle they mentioned was non availability of enough space in traditional library buildings in the universities to handle such activities.

Writing his experience in the implementation of information literacy, Jayatissa (2008) and Jayatissa (2009) explains that the unavailability of resource persons followed by the challenge of logistical issues are main concerns which affect conducting information literacy programs. This program, as he confirmed, had to be withheld due to poor attendance of students. This is due to the fact that this program was not connected or collaborated with other modules. On the other hand, it was an optional and non-credit course. As students explained, they were interested in the program, but they had many activities in relation to credit bearing courses rather than attending the noncredit course.

By analyzing information literacy programs which are being practiced in university libraries, Ranaweera (2010) reports that such programs have only covered some aspects such as information sources, information technology and information process. The most important aspects such as information control, knowledge construction, knowledge extension and wisdom conceptions have not been covered by most evaluated programs. This study also found that though the acquisition of information skills was practiced by the studied universities, the usage of information in problem solving and decision making was not satisfactorily practiced by them.

Another study conducted by Wickramanayake (2012) shows how the academic librarians in Sri Lankan universities make use of web to provide online instruction for their users. As analysis confirmed, majority of university library websites were not integrated with most of the web based instruction elements. Among classified web based instruction in the study, 'general library orientation' was the most widely used method. Even though, some 
main online library instruction tools such as 'database or software specific search skills', 'internet instruction' and 'productivity software application' etc. are duties of academic librarians, librarians considered them as duties of the computer faculty. Interestingly, face to face instruction for searching library databases and online public access catalogue (OPAC) are available onsite - online instruction for them is unavailable.

The other matter which was identified from this study is deficiency of online 'discipline or course specific research skills' and 'assignments specific tutorials' on the library websites. This discrepancy reflects the poor faculty library relationship or collaboration on online library instruction. Another finding arrived from the study is unavailability of online 'information literacy instruction' and 'academic integrity and intellectual property' in the studied websites. As information literacy is a broad subject, 'academic integrity and intellectual property' are also discussed under information literacy in the literature. Somehow, though the academic libraries had been practising some elements of information literacy in real library environment, unavailability of these practices in studied library websites shows considerable shortage.

As highlighted in the above studies, Sri Lankan academic libraries are still in the initial stage of development of onsite and online information literacy programs. Lack of proper information literacy programs in university libraries have great influence on students' information and library skills development in Sri Lanka (Jayasundara, 2007). As Ranaweera, (2010) emphasizes, there were no collaborative ventures or programs which incorporated information literacy with undergraduate curricular in Sri Lankan universities until mid of 2009. This situation still remains unchanged in most universities due to different factors. According to Wickramanayake (2014), most academic librarians had no better opportunities, facilitates and good working environment in their universities and academic libraries for the implementation of information literacy. Actually, though most academic librarians needed to implement information literacy programs for their universities, they suffered from lack of physical and human resources and training. In addition, negative attitude of faculty, administrative staff and students towards librarians' teaching and information literacy had adverse effects. 


\section{Challenges}

As discussed above, user education in Sri Lankan universities is in an indiscriminate situation. This is due to the fact that university libraries and librarians are currently facing unprecedented problems and challenges. Apparently, the reason for these changes is the development and introduction of new information literacy initiatives in the field, the rapid development of information and communication technology sector and the complex nature of user requirements. Though Sri Lankan academic librarians have understood this situation clearly, as discussed above, they cannot overcome these burdens straight away or grasp these changes due to some phenomena such as financial, training, administrative, attitudinal and policy issues. As this researcher understands, this is the most critical challenge which academic librarians in Sri Lanka face today.

In order to overcome these challenges, the researcher suggests that university librarians be able to become good team leaders. They must strategically gather all the university stakeholders such as teaching staff, administrators, nonacademic staff, students and external community by enlightening them about the requirement to strengthen the user education - specially information literacy, because though the academic librarians are keen in bibliographic instruction practices in libraries, it is a common challenge for them to achieve the highest end results from information literacy practices due to the complex nature of the subject (Miller,1992). At the same time, academic librarians must be well educated (most probably to have a Ph.D. in the field of Library and Information Science), enthusiastic and most necessarily should be able to retain their academic dignity among teaching staff because, as Peacock (2001) highlights, the academic librarians' role as a teacher or instructor is

"...often neither readily recognized nor accepted by the individual academic or the broader university, and there are a number of barriers which exist beyond the control of the library which inhibit a librarian's ability to fully participate in, and contribute to, the teaching and learning of the university (p.3)."

In addition, the academic librarians should be active partners of curricular reviewing and developing committees of the university. This involvement necessarily facilitates the library to be included some essential components of 
information literacy to the undergraduate courses of the university (Zabel, 2004).

Even more, the academic librarians should fulfill their training requirements in the relevant field to keep their knowledge and skills up to date. They must necessarily be self-motivated persons who have hard working and team working skills. In addition, such people must be research oriented which help them to develop and introduce well planned and creative new instruction programs. These developments, on the other hand, impact positively for considerable changes of attitudes of teaching staff, administrators and students on academic librarians and their teaching.

\section{Potential Opportunities}

By reviewing the above literature, we can keep great expectations regarding a favorable future of user education in university libraries because some programs discussed in the above literature have at least been made a little effort to modify / continue an existing program or to introduce new programs. This situation can clearly be identified by reviewing some local articles written by university Librarians / Senior Assistant Librarians (e.g. Jayatissa, 2008; Jayatissa, 2009; Mashroofa, 2009; \& Seneviratne, 2009) and by considering recent information literacy module which was proposed by Standing Committee of Library and Information Science (SCOLIS) of University Grants Commission (UGC) in Sri Lanka. As the SCOLIS proposed, all the state owned universities which are functioning under UGC must seek possibility to introduce credit bearing information literacy programs to ongoing undergraduate degree programs to increase students' information and library skills to enable them become critical thinkers and lifelong learners. One, in this regard, can question whether our academic librarians are trained and skillful professionals to carry on these types of multifaceted concepts successfully without having required professional training in teaching methods and information literacy. As Wickramanayake (2014) identified, majority of university librarians in the country have acquired teaching performance, but not training on information literacy teaching. However taking teaching performance of academic librarians as an advantage, the university authorities can train them in information literacy by making a little effort. As academic librarians in universities benefit from pay study leave 
equivalent to teaching staff, they must be motivated to earn postgraduate qualifications on user education - specially on information literacy.

The establishment of National Institute of Library and Information Science (NILIS) in 1999 was another significant landmark in the field of library and information science in Sri Lanka. Though the primary objective of the institution is to train and educate school librarians, the NILIS conducts other postgraduate programs as provision given by NILIS Ordinance. Thus, librarians of higher education institutions in the country have a great opportunity to learn and train in user education - especially in information literacy because the institution is composed of information literacy elements mostly in its course modules. The information literacy education of the NILIS was much enlightened in 2004 with the introduction and application of 'Empowering 8' information literacy module. In fact, involvement of NILIS in user education - especially in information literacy created a new awakening in the country. Even the NILIS did a dominant role to publicize the concept 'information literacy' throughout the country. Thus the authorities of the institution have a leading responsibility to broaden its scope to provide better service for information literacy development.

Seneviratne (2009) reported how the library instruction activities in University of Moratuwa are gradually changing to information literacy courses. From 2000, the library of University of Moratuwa introduced different activities such as producing user guides, developing and modifying their website to integrate information literacy tutorials/ user guides/ instructional documents/ virtual tours and frequently asked questions, etc. In addition, from 2002, the library included audio visual aids for user orientation programs and regular user education programs to make students aware of the development of library website, online public access catalogue and electronic journals.

Collaboration among different groups and university librarians in library instruction creates another opportunity for university libraries to succeed in their instructional programs. The 'Communication Skills Development Program' of university of Moratuwa is a good example for university collaboration. The main objective of this program was to make newly enrolled students familiar with the university system before attending formal course 
programs. While this program was working with various subject and service areas of the university, it was allocated considerable teaching periods for information literacy program (Seneviratne, 2009). Bruce, (1995) was also of the opinion that academic libraries or academic librarians should always look at the possibility to integrate this type of activity with faculty, computer scientists, media specialists, and sometimes with community stakeholders to increase collaboration among these groups. Thus, collaboration in return helps the library to develop well defined information literacy programs for the benefit of the university students. However, though teaching faculty is somewhat disinclined about librarians' teaching, they would like to render their supports for instructional development in academic libraries (Wickramanayake, 2014). This is much beneficial for academic library administrations to develop mutual understanding between two parties and to increase efficiency of ongoing user education programs.

Another beneficial activity which academic librarians effectively applied is organizing and conducting library instruction / information literacy workshop. University library administrations have the opportunity to conduct these types of workshops for students, librarians and academic and non-academic staff. Mashroofa (2009) reports how the special workshop conducted for students in the special degree program in social sciences of the South Eastern University of Sri Lanka was beneficial. This workshop aimed to develop information literacy skills of students including information evaluation skills, usage and effective application of information for learning and research activities.

At the end of the workshop, the students reported that they were able to use library and its resources effectively, formulate research questions, evaluate the quality of information obtained, avoid plagiarism and use accepted citation styles for both print and online resources. Furthermore, the majority of participants responded that the workshop was very much useful/ helpful for their learning and academic activities.

According to Seneviratne (2009), with the establishment of 'User education Unit' in 2006, the library of University of Moratuwa conducted a variety of workshops and seminars for the student community to educate them under special topics such as effective online searching techniques, online public 
access catalogue, literature searching, electronic information sources, managing references, etc.

In addition some workshops conducted by external groups such as 'Programme for the Enhancement of Research Information' (PERI) of 'International Network for the Availability of Scientific Publications' (INASP) to train academic librarians in information literacy were of immense contribution for the development of skills of academic librarians in the said subject. Thus, having more and more workshops and training programs for librarians, students and academic and non-academic staff are much beneficial for the development of information literacy.

Despite the above development in user education, Wickramanayake (2012) clarifies how the web based library instruction was developing in university libraries in Sri Lanka. Though this article shows considerable discrepancy of web based instruction elements in studied websites, it has identified some potentials through them due to availability of some instructional web links which were under construction. The author identifies this as a constructive signal about favorable future of online user education in university libraries.

\section{Conclusions}

The present literature review identified major constraints, capabilities, weaknesses, problems and strengths of ongoing user education programs in university libraries in Sri Lanka. University administrators, librarians and policy makers can make use of this review as a supporting document while changing existing traditional user education methods to information literacy programs as well as developing new information literacy programs in university libraries. In addition, as this study emphasized, the above authorities can take necessary measures to re-evaluate the academic library organization structure by emphasizing library instruction / information literacy.

In addition, to overcome barriers associated with the development of user education methods in the sector of higher education, the university library administrations should introduce regular assessment mechanisms for user 
education programs while promoting library instruction / information literacy as a core library service in their organizations. Also, collaborative efforts are required among all stakeholders in higher education in planning, developing and implementing user education policies which ultimately will have an effect on successful instruction programs. Specially, faculty - librarians' collaboration is very essential in applying such theories into practice.

Providing funds, release time, training and professional development programs are essential to increase instructional performance of academic librarians. Equally, motivating and encouraging academic librarians to practice more on pedagogical development activities and recognizing academic librarians' teaching for annual reviews and promotion decisions are the other most important elements which have an effect on the effectiveness of library instruction programs. The positive attitudes, thorough understanding and active involvement of academics, administrative staff and librarians on information literacy and introduction of compulsory/ elective information literacy courses for students' learning are also very important in developing user education in university libraries in Sri Lanka.

\section{References}

Ashoor, M. (2005). Information Literacy: A Case Study of the KFUPM Library. The Electronic Library, 23(4), 398-409.

Bewick, L., \& Corrall, S. (2010). Developing librarians as teachers: A study of their pedagogical knowledge. Journal of Librarianship and Information Science, 42(2), 97-110.

Breivik, P.S. (1999). Take II- information literacy: revolution in education. Reference Services Review, 27(3), 271-275.

Bridgland, A., \& Whitehead, M. (2004). Information Literacy in the "E" Environment: An Approach for Sustainability. The Journal of Academic Librarianship, 31(1), 54-59.

Bruce, C. (2000). Information literacy research: dimensions of the emerging collective consciousness. Australian Academic \& Research Libraries, 31(2), 91-109.

Bruce, C.S. (1995). Information Literacy: A Framework for Higher Education. The Australian Library Journal, 44(3), 158-170.

Butcher, K. (1999). Reflections on Academic Librarianship. The Journal of Academic Librarianship, 25(5), 350-353. 
Campbell, S. (2004). Defining information literacy in the 21st century. Paper presented at the World Library and Information Congress - 70th IFLA General Conference and Council (August 22-27). Buenos Aires, Argentin. Retrieved from http://www.ifla.org/IV/ifla70/papers/059e-Campbell.pdf

Chopra, H.R. (2001). User education: training the librarians to use new technologies in the developing countries. In Proceedings of the 67th IFLA Council and General Conference (August 16-25). The Hague, IFLA. Retrieved from http://www.ifla.org/IV/ifla67/papers/072126e.pdf

Cowgill, A., Beam, J., \& Wess, L. (2001). Implementing an Information Commons in a University Library. The Journal of Academic Librarianship, 27(6), 432-439.

Dewald, N.H. (1999). Transporting Good Library Instruction Practices into the Web Environment: An Analysis of Online Tutorials. The Journal of Academic Librarianship, 25(1), 26-32.

Downard, K. (1992). User Education in Academic Libraries. Library Management, 13(3), 29-38.

Doyle, C.S. (1994). Information literacy in an information society: A concept for the information age. Syracuse, New York: Information Resources Publication, Syracuse University.

Fjällbrant, N., \& Malley, I. (1984). User education in libraries ( $2^{\text {nd }}$ ed.). London: Clive Bingley.

Fjällbrant, N. (1977). Planning a Programme of Library User Education. Journal of Librarianship and Information Science, 9(3), 199-211.

Fjällbrant, N. (2000). The development of Web-based programs to support information literacy courses. In C. Bruce \& P.C. Candy (Eds.), Information literacy around the world: advances in programs and research (pp. 25-36). Wagga Wagga, NSW: Charles Stuart University.

Grafstein, A. (2002). A Discipline-Based Approach to Information Literacy. The Journal of Academic Librarianship, 28(4), 197-204.

Hindagolla, B.M.M.C.B. (2012). Restructuring of user education programmes in university libraries from user perspectives: a case study. Journal of the University Librarians Association, 16(1), 19-33.

Homann, B. (2001). Difficulties and new approaches in user education in Germany. In proceedings of the 67th IFLA Council and General Conference, August 16-25, 2001(pp. 1-8). Retrieved from http://www.eric.ed.gov/PDFS/ED 459752.pdf

Jayasundara, C.C. (2007). An identification of Critical Success Factors (CSFs) on user perspectives in diffusing e-Information Service in the 
University of Colombo Library. Sri Lankan Journal of Librarianship and Information Management, 2(2), 1-12.

Jayatissa, L.A. (2008). Developing information literacy skills at the University of Kelaniya -starting points. LINK Connecting Commonwealth Librarians, 4(August), 6-7.

Jayatissa, L.A. (2009). A multifaceted program for information skills development: University of Kelaniya. Journal of the University Librarians Association of Sri Lanka, 13(special issue), 5-22.

Julien, H. (1998). User Education in New Zealand Tertiary Libraries: An International Comparison. The Journal of Academic Librarianship, 24(4), 304-313.

Lwehabura, M.J., \& Stilwell, C. (2008). Information literacy in Tanzanian universities: Challenges and potential opportunities. Journal of Librarianship and Information Science, 40(3), 179-191.

Manchester Metropolitan University. (2007). Information literacy: a literature review. Retrieved from http://www.learnhigher. mmu.ac.uk/research/

Mashroofa, M.M. (2009). New vistas of information literacy education: A case from South Eastern University. Journal of the University Librarians Association of Sri Lanka, 13(special issue), 23-36.

McCartin, M. (2001). A grass-roots approach to integrating information literacy into the curriculum. In B. I. Dewey (Ed.), Library user education: Powerful learning, powerful partnerships (pp. 167-174). Lanham, MD: Scarecrow Press.

McMullen, S. (2001). Usability testing in a library Web site redesign project. Reference Services Review, 29(1),7-12.

Meer, P.F.V. (2000). Pushing the limits: creative web use in libraries related to instruction. Research Strategies, 17(4), 237-256.

Miller, W. (1992). The future of bibliographic instruction and information literacy for the academic librarian. In B. Baker, M. E. Litzinger, R. Hensley \& B. Sandore (Eds.), The evolving educational mission of the library (pp. 140-157). Chicago: Association of College and Research Libraries.

Oblinger, D.G., Barone, C.A., \& Hawkins, B.L. (2001). Distributed education and its challenges: An overview. Washington D.C.: American Council on Education centre for policy analysis. Retrieved from http://www.acenet.edu/bookstore/pdf /distributedlearning/distributed-learning-01.pdf

Peacock, J. (2001). Teaching skills for teaching librarians: Postcards from the edge of the educational paradigm. Australian Academic and Research Libraries, 32(1),1 - 11. 
Rader, H. (1991). Bibliographic instruction or information literacy. College and Research Libraries News, 51(1), 18-20.

Ragains, P. (2001). A primer on developing and using course-related library Webpages. Research Strategies, 18(1), 85-93.

Ranaweera, P. (2010). Information literacy programs conducted by the universities in Sri Lanka. Journal of the University Librarians Association of Sri Lanka, 14(1),61- 74.

Rathnayake, A.R.M.M. (2004). Library user education programs in Sri Lankan universities: an overview. Journal of the University Librarians' Association of Sri Lanka, 8, 54-64.

Sacchanand, C. \& Jaroenpuntaruk, V. (2006). Development of a web-based self-raining package for information retrieval using the distance education approach. The Electronic Library, 24(4), 501-516.

Seaman, N.H. (2001). Information Literacy: A Study of Freshman Students' Perceptions, with Recommendations (unpublished doctoral Dissertation).Virginia Polytechnic Institute and State University, Blacksburg, Virginia.

Seneviratne, T.M. (2009). Going the extra mile: Information skills development at University of Moratuwa. Journal of the University Librarians Association of Sri Lanka, 13(special issue), 37-52.

Sinikara, K., \& Järveläinen, L. (2003). Information literacy development in Finland. Library Review, 52(7), 333-339.

Smith, S.S. (2010). Web-Based Instruction: A Guide for Libraries ( $3^{\text {rd }}$ ed.). Chicago: American Library association.

Snavely, L., \& Cooper, N. (1997).The Information Literacy Debate. The Journal of Academic Librarianship, 23(1), 9-14.

Townley, C.T., \& Myers R.D. (1995). Managing Electronic Information Literacy Education. In Donald A. Barclay (ed.),Teaching Electronic Information Literacy: a How-to-do-it Manual (p. 163).New York: Neal-Schuman Publishers.

Virkus, S. (2003). Information literacy in Europe: a literature review. Information Research 8(4). Retrieved from http://informationr.net/ir/8-4/paper159.html

Virkus, S., \& Metsar, S. (2004).General Introduction to the Role of the Library for University Education. LIBER QUARTERLY, 14, 290305.

Warnken, P. (2004). The Impact of Technology on Information Literacy Education in Libraries. The Journal of Academic Librarianship, 30(2), 151-156.

Weiss, S.C. (2003).The origin of library instruction in the United States 1820-1900.Research Strategies, 19(3-4), 233-243. 
Wickramanayake, L. (2012). Instruction and help services in the academic library websites and web pages in Sri Lanka: a content analysis. The Electronic Library, 30(3), 377 - 389.

Wickramanayake, L. (2014). An assessment of academic librarians' instructional performance in Sri Lanka: a survey. Reference Services Review, 42(2), 364-383.

Wijetunge, P. (1998). A descriptive survey of library and information science education personnel in Sri Lanka. Asian Libraries, 7(11), 315-324.

Wijetunge, P., \& Alahakoon, U.P. (2005). Empowering 8: the Information Literacy model developed in Sri Lanka to underpin changing education paradigms of Sri Lanka. Sri Lanka Journal of Librarianship \& Information Management, 1(1), 31-41.

Wijetunge, P., \& Willson, J. (1998). Perceptions of Library and Information Science Education and Training in Sri Lanka, In Proceedings of 64th IFLA General Conference, Amsterdam: IFLA. Retrieved from http://archive.ifla.org/IV/ifla64/056-140e.htm.

Willingham, P., Carder, L., \& Millson-Martula, C. (2006). Does a Border Make a Difference? Library Instruction in the United States and Canada. The Journal of Academic Librarianship, 32(1), 23-34.

Wilson, K.M., \& Halpin, E. (2006). Convergence and professional identity in the academic library. Journal of Librarianship and Information Science, 38(2), 79-91.

Yi, H. (2005). Library instruction goes online: An inevitable trend. Library Review, 54(1), 47-58.

Zabel, D. (2004). A Reaction to "Information Literacy and Higher Education". The Journal of Academic Librarianship, 30(1), 17-21. 